The publishers of Philosophic Abstracts take pleasure in announeing for Summer 1941 publication

\title{
THE DICTIONARY OF PHILOSOPHY
}

Although embraced in one volume, the dictionary covers metaphysics, ethics, epistemology, logie, philosophy of religion, esthetics, philosophy of law, philosophy of education, social philosophy and philosophical psychology. Special emphasis has been placed on the definition of basic concepts and terms germane to the contemporary schools of philosophy, logical positivism, dialectical materialism, mathematical logic, neo-scholasticism, philosophy of seience, Chinese, Jewish and Indian philosophy.

The DIOTIONARY OF PHILOSOPHY is edited by Dagobert D. Runes with the collaboration of Alonzo Church, Rudolf Carnap, G. Watts Cunningham, Edgar Sheffield Brightman, Irwin Edman, Rudolf Allers, A. C. Ewing, Ralph Tylex Flewelling, Jorgen Jorgensen, Ledger Wood, William Marias Malisoff, Carl G. Hempel, B. A. G. Fuller, A. Cornelius Benjsmin, Hunter Guthrie, Wilbur Long, V. J. McGill, A. O. Pegis, Glenn R. Morrow, Jeseph Ratner, Wendell T. Bush, Dorion Cairns, James K. Feibleman, Paul A. Schillp, Paul Weiss and a number of other scholars.

Applieations for further literature, as well as other communications, shonld be addressed to:

\section{PHILOSOPHIC ABSTRACTS}

15 East 40th Street

New York City

\section{Readers of the REVIEW OF POLITICS Should also Read}

BLACKFRIARS

The Monthly Review Edited By

The English Dominicans

It seeks to give in the English tongue what its virile French contemporaries "La Vie Spirituelle," and "La Vie Intellectuelle" have been giving to the French reading public:

\section{THE SPIRITUAL and CULTURAL BACKGROUND TO POLITICS and SOCIETY}

$\$ 3$ for One Year's Subscription from BASIL BLACKWELL, LTD. Broad St., Oxford, England 


\section{WATCH EUROPE}

Through the Columns of

\section{THE TABLET}

(Edited by Douglas Woodruff)

RECENT CONTRIBUTIONS INCLUDE:

M. C. D'Arcy, S.J.; Maurice Baring; Hilaire Belloc; J. Brodrick, S.J.; Thomas Gilby, O.P.; G. M. Godden; Christopher Hollis: Philip Hughes; Reginald Jebb: Humphrey J. T. Johnson; Ronald Knoxi Shane Leslie; David Mathew; Robert Speaight: R. H. Steuart, S.J.; Herbert Thurston, S.J.; E. I. Watkin and Evelyn Waugh.

Send $\$ 1.00$ for Trial 3 Months Subscription To-day to THE MANAGER

THE TABLET. 39 Paternoster Row London E.C.L. England

\section{DEMOCRACY OR ANARCHY?}

A Study of Proportional Representation

By F. A. Hermens

Associate Professor of Politics, University of Notre Dame

Preface by C. J. Friedrich

Professor of Government, Harvard University

The central theme of this book is that democracy has in most countries given way to dictatorship because it has stressed liberty to the extent of ignoring the need for authority.

$$
\text { Price, } \$ 4.00
$$

Address orders to

THE REVIEW OF POLITICS

University of Notre Dame, Notre Dame, Indiana 